\title{
The Effect of Edmodo on Students' Writing Skill in Recount Text
}

\author{
Fauzi, A. ${ }^{1}$ \\ ${ }^{1}$ Department of English Education, Faculty of Teacher Training and Education, Sebelas Maret \\ University, Surakarta, Indonesia \\ Corresponding email: adinfauzy@gmail.com
}

\begin{abstract}
This study investigates the effect of Edmodo on students' writing skill in recount text. The participants of the study were 9 students of Excellent Class of a Senior High School in Tulungagung, Indonesia. A pre-experimental study was employed as the research design to investigate the effectiveness of Edmodo in recount writing instruction. Following the research design, the students participated as both experimental and control groups. They did pretest at the beginning of this study, received treatment, and did posttest at the end of the study. The finding of the study revealed that the null hypothesis could be rejected. The convention to reject the null hypothesis is that when the p-value of the obtained statistics is less than 0.05. The finding showed that $\mathrm{p}$-value was less than $0.05(0.006<0.05)$. Referring to the data, there was enough evidence indicating that the null hypothesis could be rejected, and thus it could be concluded that using Edmodo was effective to teach recount text. This study attempts to contribute to the improvement of teaching writing by maximizing the use of ICT tools. Using Edmodo, both students and teachers can have a safe online environment to conduct more effective and sustainable teaching and learning process.
\end{abstract}

Keywords: Edmodo; recount text; writing skill

DOI: http://dx.doi.org/10.20961/ijpte.v1i2.5038 


\section{INTRODUCTION}

It is generally argued that writing is the most difficult skill to master (Fauziati, 2015, p. 123). The difficulties are apparent both in the process of writing and skills needed in writing. Bell and Burnaby (1984, as cited in Nunan, 1989, p. 36) point out that writing is an extremely complex cognitive activity in which the writer is required to demonstrate control of a variables simultaneously. At the sentence level these include control of content, format, sentence structure, vocabulary, punctuation, and spelling (Bell and Burnaby, 1984; Murcia, 2000). Beyond the sentence, the writer must be able to structure and integrate information into cohesive and coherent paragraph and text. In addition, Nunan (1989, p. 39) points out that to be a successful writer, students must have several skills such as (1) mastering the mechanics of letter formation, (2) mastering and obeying conventions of spelling and punctuation, (3) using the grammatical system to convey one's intended meaning, (4) organizing content at the level of paragraph and the complete text to reflect given or new information and topic or comment structures, and (5) selecting an appropriate style for one's audience. Considering the complexity of writing which are previously stated, it is not a surprising fact that very often, students find themselves in a trouble in writing since they have no idea of what to write, and how to write. Meanwhile, to be successful in writing, those indicators must be understood and used by students. To teach writing, therefore, teachers need to select appropriate method, technique, or media to help students in writing.

There are numerous teaching media that can be applied in teaching writing either traditional media or modern/digital media. Without underestimating the role of traditional media, digital media is in fact more largely accepted and widely used by either teachers or students recently rather than traditional media (Purcell et al., 2013). Dealing with this phenomenon, teachers can select digital media which are appropriate and applicable in teaching writing. In the context of teaching writing, Edmodo is one of the effective tools. Accordingly, Edmodo is a free and secure learning platform which is free of advertisements, games and other distractions used to provide a simple way for teachers to create and manage online classroom, and enable students to connect with teacher and other students anywhere and anytime (Balasubramanian, Jaykumar, \& Fukey 2014; Thongmak, 2013; ShamsAbadi, Ahmadi, \& Mehrdad, 2015; Al-Khatiri, 2015). In teaching writing, Edmodo has some advantages as follows: (1) it offers quick access to writing materials and assignments, (2) combined with particular approach or method or technique, Edmodo leads students to have better organization in writing, (3) Edmodo facilitates either teacher to give feedback on students' shared writing, or students to receive feedback on their writing from their peers and the teacher to make it as considerations in revising and editing their writing, and (4) Edmodo makes students more interested in writing (Stroud, 2010; Balasubramanian, Jaykumar, \& Fukey, 2014; Purnawarman, Susilawati, \& Sundayana, 2016; Shams-Abadi, Ahmadi, \& Mehrdad, 2015).

Indeed, using Edmodo solely as teaching media is ineffective. To make Edmodo function well, teachers should com 
plement Edmodo with appropriate approach that can provide effective teaching steps. In this context, White \& Arndt (1991, as cited in Hasan \& Akhan, 2010) provides a framework of process writing as follows

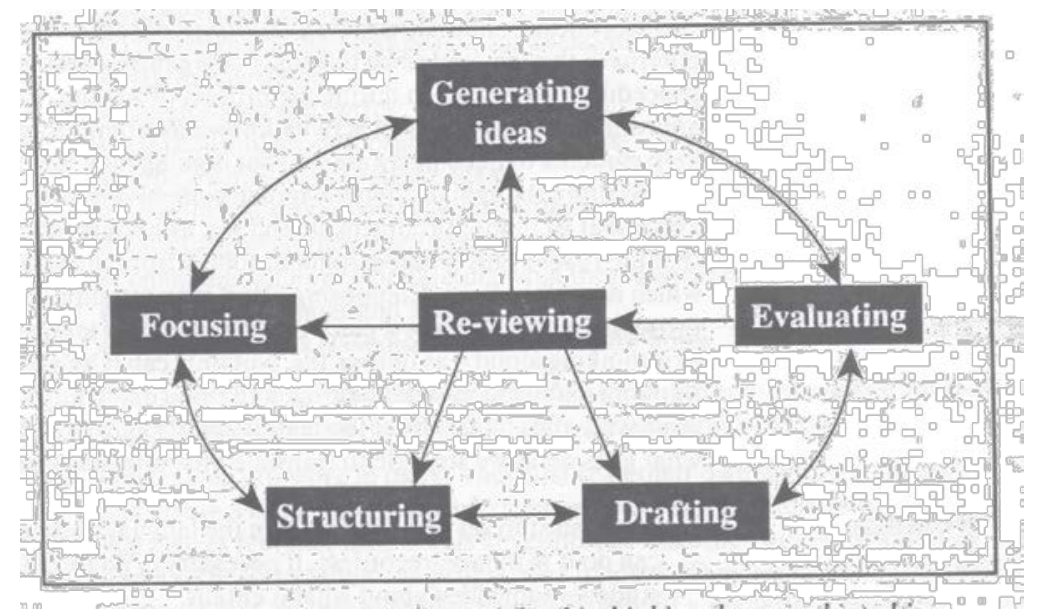

Fig. 1: Process Writing Framework

The framework depicts that in producing a piece of writing, some processes must be followed by the students. To simplify, there are four typical stages of process writing namely planning, drafting, revising, and editing (Tribbel, 1996, as cited in Badger \& White, 2000). At the drafting stage students would select and structure the result of the brainstorming session. After discussion, students might revise the first draft individually or in groups. Finally, the learners would edit or proof-read the text (Badger \& White, 2000).

Early studies revealed that using Edmodo in teaching writing is more effective than using traditional media. Shams-abadi et al. (2015) investigated the effect of Edmodo on EFL learners' writing performance. The result showed that the use of Edmodo in writing was more effective on EFL learners' writing performance participating in this study. Similarly, Al-Khatiri (2015) investigated the prospects of integrating Edmodo into Saudi EFL female secondary school instruction. It concentrated on students' perceptions and challenges regarding Edmodo use and its effect on their attitudes towards EFL learning. Findings of the post-treatment questionnaire show that students' perceptions towards Edmodo were highly positive and that although there were considerable challenges to its integration. Notably, some studies focusing on using Edmodo to teach writing (see, Lara, 2013; Shams-abadi et al., 2015) proved that this learning platform is an effective media to improve students writing. Those studies, however, were lack of specific information on what genre in which Edmodo was implemented. Therefore, this study is attempted to give a more focused result; that is, the effect of Edmodo in teaching writing especially recount text.

\section{METHOD}

This study was a pre-experimental one group pre-test post-test design. In the simplest pretest-posttest design, researchers gather data about some outcome through a single pretest, administer a treatment, and then gather posttest data on 
the same measure (Bell, 2010). The sample of the study were 9 students of $X$ Excellent Class of a Senior High School in Tulungagung, Indonesia. The rationale of using only one group without any control group was simply because there was only one classroom in X Excellent program at the school. Consequently it was impractical to select the control group from other programs (Regular and Acceleration) since the level among the three programs was definitely different. It addition, it was found that only in Excellent program in which the students had their own personal computer or laptop so that it could ease them to follow the instruction in this study.

In collecting the data, two instruments were used in this study; that is, writing test and scoring rubric. Writing test was projected to elicit and collect information on students' writing skill before and after giving treatment. Meanwhile, scoring rubric was used as guidance in scoring the students' writing. Dealing with the test, there were two tests in this research; pretest, and posttest. The researcher ascertained that the pretest provided instructions which differ in form or wording from the posttest, though the two tests must test the same content, e.g. they were alternate forms of a test for the same groups. To clarify, the form of test was recount writing test.

Dealing with the investigation the effectiveness of Edmodo in this research, the data were analyzed from students' pretest and posttest scores. The data which were obtained from both occasions then were analyzed by using Paired Samples Test in IBM SPSS Statistics 20. If the result of $t_{\text {table }}$ is bigger than $t_{\text {obtained }}$ at the level of significance 0.05 , the null hypothesis cannot be rejected indicating that Edmodo is not effective to teach writing especially recount text. By contrast, if $t_{\text {obtained }}$ is bigger than $t_{\text {table }}$ at the level of significance 0.05 , the null hypothesis can be rejected indicating that Edmodo is effective to teach writing especially recount text.

\section{RESULT}

As previously mentioned, there were two occasions of writing assignments in this study; pretest and posttest. In pretest, the students started making the first draft in the classroom, and after they were given feedback, they could revise and edit their works out of the classroom. The same process was also applied in posttest in which students should make the first draft in the classroom, and feedback was given, they could rework their writing out of the classroom. The difference was apparent in the media used for submitting their writing; in pretest students used paper-pencil test, while in posttest students completely use word processor and Edmodo to share their writing and receive feedback. After doing all of the steps in process writing either in pretest or posttest, the majority of students show a significant progress in terms of the score of their writing. Table 1 shows the result of students' score in pretest and posttest. 
Table 1 Pretest and Posttest Data

\begin{tabular}{cccc}
\hline No. & Student & Pretest & Posttest \\
\hline 1. & A & 65 & 70 \\
2. & B & 70 & 70 \\
3. & C & 80 & 90 \\
4. & D & 65 & 80 \\
5. & E & 85 & 95 \\
6. & F & 65 & 85 \\
7. & G & 65 & 65 \\
8. & H & 60 & 80 \\
9. & I & 85 & 90 \\
\hline
\end{tabular}

After obtaining quantitative data from the students score calculated from the scoring rubric, the researcher made the data set meaningful by calculating the data using descriptive statistics to find out the mean, the median, the standard deviation, the variance, the minimum and the maximum. Table II shows the result of descriptive statistics.

Table 2 Descriptive Statistics

\begin{tabular}{lccccccc}
\hline & Range & $\begin{array}{l}\text { Mini- } \\
\text { mum }\end{array}$ & $\begin{array}{l}\text { Maxi- } \\
\text { mum }\end{array}$ & Sum & Mean & $\begin{array}{l}\text { Std. } \\
\text { Deviation }\end{array}$ & Variance \\
\hline Pretest & 25.00 & 60.00 & 85.00 & 640.00 & 71.1111 & 9.61047 & 92.361 \\
Posttest & 30.00 & 65.00 & 95.00 & 725.00 & 80.5556 & 10.44164 & 109.028 \\
$\begin{array}{l}\text { Valid N } \\
\text { (listwise) }\end{array}$ & & & & & & & \\
\hline
\end{tabular}

As Table 2 shows, the mean of post-test scores (80.5) is larger than the mean of pre-test scores (71.1). It indicates that on average, the use of Edmodo has caused the improvement of students' scores, but it is important to know that such a conclusion is only a descriptive conclusion. It should be tested about being meaningful this progress. Therefore, to investigate whether Edmodo is effective to teach recount text, the researcher tested the results of pretest and posttest by using Paired Sample Test in IBM SPSS Statistics 20. Table III depicts the results of the test.

Table 3 Inferential Statistics

\begin{tabular}{|c|c|c|c|c|c|c|c|c|}
\hline & \multicolumn{5}{|c|}{ Paired Differences } & \multirow[t]{3}{*}{$\mathbf{T}$} & \multirow[t]{3}{*}{ Df } & \multirow{3}{*}{$\begin{array}{l}\text { Sig. (2- } \\
\text { tailed) }\end{array}$} \\
\hline & \multirow[t]{2}{*}{ Mean } & \multirow{2}{*}{$\begin{array}{c}\text { Std. } \\
\text { Deviati } \\
\text { on }\end{array}$} & \multirow{2}{*}{$\begin{array}{l}\text { Std. } \\
\text { Error } \\
\text { Mean }\end{array}$} & \multicolumn{2}{|c|}{$\begin{array}{c}\text { 95\% Confidence Interval } \\
\text { of the Difference }\end{array}$} & & & \\
\hline & & & & Lower & Upper & & & \\
\hline $\begin{array}{l}\text { Pretest - } \\
\text { Postest }\end{array}$ & -9.44 & 7.69 & 2.56 & -15.35 & -3.538 & -3.69 & 8 & .006 \\
\hline
\end{tabular}

Referring to Table 3, it was noted that $t_{\text {obtained }}$ is -3.538 . The way to test whether null hypothesis can be rejected is that by comparing the result of $t_{\text {obtained }}$ and $t_{\text {table }}$. If the result of $t_{\text {obtained }}$ is larger than $t_{\text {table }}$ at the level of significance 0.05 , the null hypothesis can be rejected. On the contrary, if the result of $t_{\text {obtained }}$ is smaller than $t_{\text {table }}$, the null hypothesis cannot be rejected. In consulting to $t_{\text {table }}$, the researcher needed to find out the degree of freedom. As 
can be seen in Table 3 that $D f$ (Degree of freedom) is 8 , the researcher consulted to the $t_{\text {table }}$, and at the level of significance 0.05 , the value of $t_{\text {table }}$ is \pm 2.306 . Comparing to the value of $t_{\text {table }}$, the value of $t_{\text {obtained }}$ is larger $(-2306<-3.538)$. Also, the way to test whether the null hypothesis can be rejected is by comparing $\mathrm{p}$-value with the standard level of significance, 0.05 . The convention to reject the null hypothesis is that when the p-value of the obtained statistics is less than 0.05 (Balnaves \& Calputi, 2001). As Table 3 shows, the p-value is less than 0.05 $(0.006<0.05)$. Thus, there was enough evidence indicating that the null hypothesis could be rejected, and thus it could be concluded that using Edmodo was effective to teach recount text.

\section{DISCUSSION}

This present study investigates the effects of Edmodo on students' writing skills in recount text. Positively, the result of the study shows that the scores of posttest were better than the scores of pretest at the end of the study. This finding shows that the use of digital technologies like Edmodo can shape students' writing myriad ways including in generating ideas, composing, revising, and editing, from a single word to a lengthy essay. The implementation of Edmodo in writing process in this study is obviously effective to make students experience more meaningful process of writing. This finding is consistent with Purcell et al. (2013).

Besides, when conducting online session using Edmodo, teachers can give the students quite time to understand the material, and then giving response. In giving response, students have a longer time to compose a good sentence so that their response will not lead to a misunderstanding. This process was found in the implementation of peer feedback in which students are given chance to give comment on other students' writing. In this context, this finding is consistent with Lie (2013) that using online social network like Edmodo, students can improve their writing skills precisely through the process of giving response. In addition, the finding in general is also in compliance with Dogoriti et al. (2014) showing the usefulness of social media as an adjunctive instructional tool which can facilitate the development of students' language skills, reinforced their cognitive skills and supported an active learning environment.

Finally, it was confirmed that using Edmodo in writing would lead to better result than using conventional or traditional media. The result of this research indicates that Edmodo was effective to teach writing proved from the improvement of students score from pre-test to post-test. This is consistent with some prior studies conducted by Shams-abadi et al. (2015) and Lara (2013) figuring out that after being taught using Edmodo, students could achieve better score in writing tasks.

\section{CONCLUSION}

The results of this study indicated that there was a significant difference in the students' score after being taught using Edmodo. In this context, it can be concluded that writing through Edmodo would lead to better result of writing. Particularly, Edmodo is capable of assisting teachers to make content 
understandable, check students' understanding, elicit students' responses, and encourage interpersonal communication. Notably, it is suggested for the English teachers to use Edmodo to change their traditional classrooms. Besides, the students can use Edmodo not only to submit assignment, but also to see their progress overtime, share information, access relevant resources, etc. To review, this study attempts to contribute to the better integration of ICT-based media in ELT especially teaching writing. However, due to the limitation of this study; that is, a small number of the participants, the researcher could not suggest that the findings of this research can be generalized to the larger population. Therefore, it is suggested for future researchers to conduct more empirical studies with a larger sample by using either quantitative or qualitative research methods to provide better illumination of the issue.

\section{REFERENCES}

Al-Khatiri, F. (2015). Beyond the classroom walls: Edmodo in Saudi secondary school EFL instruction, attitudes and challenges. English Language Teaching, 8 (1), 189-204.

Badger, R., \& White, G. (2000). A process genre approach to teaching writing. ELT Journal, 54 (2), 153-160.

Balasubramanian, K., Jaykumar, V., \& Fukey, L. N. (2014). A study on "student preference towards the use of Edmodo as learning platform to create responsible learning environment.” Procedia - Social and Behavioral Sciences 144, 416 - 422.

Balnaves, M., Caputi, P. (2001). Introduction to quantitative research methods: An investigative approach. London, California, New Delhi: Sage Publication.

Bell, A. B. (2010). Pretest-posttest design. In Encyclopedia of Research Design. (pp. 1087-1092). Retrieved from http://dx.doi.org/10.4135/9781412961288.n331

Bell. J., \& Burnaby. B. (1984). A handbook for ESL literacy. Toronto: OISE Press.

Dogoriti, E., Pange, J., \& Anderson, G.S. (2014). The use of social networking and learning management systems in English language teaching in higher education. Campus-Wide Information Systems, 31(4), 254-263.

Fauziati, E. (2015). Teaching English as a foreign language. Surakarta: Era Pustaka Utama.

Lara, V. D. (2013). The improvement of writing based on a genre approach through the use of an e-learning platform (Unpublished Thesis). University of Veracruz, Veracruz.

Lie, A. (2013). Social media in a content course for the digital natives. TEFLIN Journal, 24(1), 48-62.

Murcia, C., Marianne. \& Olshtein E. (2000). Discourse and context in language teaching. Cambridge: Cambridge University Press.

Nunan, D. (1989). Designing task for the communicative classroom. Cambridge: Cambridge University Press

Purcell, K., Buchanan, J., Friedrich, L. (2013). The impact of digital tools on student $\quad$ writing and how writing is taught in schools. Retrieved from http://www.pewinternet.org/

Purnawarman, P., Susilawati, \& Sundayana, W. (2016). The use of Edmodo in teaching writing in a blended learning setting. Indonesian Journal of Applied Linguistics, 5 (2), pp. 242252.

Shams-Abadi, B. B., Ahmadi, S. D., \& Mehrdad, A. G. (2015). The effect of Edmodo on EFL learners' writing performance. International Journal of Educational Investigations, 2(2), 88-97.

Stroud, C. (2010). Edmodo: A white paper. Retrieved from $\quad$ http://coe.winthrop.edu/.

Thongmak, M. (2013). Social network system in classroom: Antecedents of Edmodo Adoption. Journal of e-Learning and Higher Education, 1-15. 